\title{
Feeding selectivity of the herbivorous fish Scartichthys viridis: effects on macroalgal community structure in a temperate rocky intertidal coastal zone
}

\author{
F. Patricio Ojeda*, Alejandro A. Muñoz** \\ Departamento de Ecología, Facultad de Ciencias Biológicas, P. Universidad Católica de Chile, Casilla 114-D, Santiago, Chile
}

\begin{abstract}
The ecological importance of fish herbivory was examined in a temperate rocky intertidal zone along the central Chilean coast. In this system, the blenny Scartichthys viridis is the most abundant and only herbivorous fish. We describe its diet, determine its field food selectivity (gut contents vs macroalgal field availability comparison), and report on its laboratory dietary preferences in a multiplechoice feeding experiment. Finally, we evaluate the relative effects of fish herbivory and grazing invertebrates on macroalgal abundance, distribution and diversity patterns in the field, using replicated exclusion cages to manipulate grazing intensity. $S$. viridis was found to be a selective grazer; its diet was dominated by 2 macroalgae: the green Ulva and the red Gelidium, representing 32.6 and $41.4 \%$ of its total gut content biomass, respectively. Ulva was consumed much above its field availability while Gelidium was selected only during fall-winter. In the laboratory, S. viridis selected the green macroalgae Ulva rigida and Codium dimorphum and avoided Gelidium chilense. We suggest that Gelidium may be included in its diet due to the limited availability of Ulva in the field. Experimental exclusion of this fish from rocky surfaces resulted in increased abundance of green foliose macroalgae (U. rigida and Enteromorpha linza), and, to a much lesser extent, of the red foliose macroalgae $G$. chilense, Porphyra columbina, and Mazzaella laminarioides, and of the brown macroalgae Colpomenia phaeodactyla and Petalonia fascia, as well as an extension of the distribution of $P$. columbina from the high intertidal to the mid intertidal zone, where it normally does not occur. Exclusion of grazing invertebrates resulted in a decrease in foliose macroalgal species richness, but had no effect on biomass. To our knowledge, this is the first experimental demonstration of the effect of an herbivorous fish on macroalgal community structure in a temperate rocky intertidal area. The selective feeding displayed by $S$. viridis, its high numerical abundance, and the results of the herbivore exclusion experiment suggest its importance in maintaining the low abundance of foliose macroalgae and the high relative cover of brown and red crustose macroalgae, characteristic of many low to mid rocky intertidal areas along the coast of central Chile.
\end{abstract}

KEY WORDS: Herbivorous fish - Temperate waters - Rocky intertidal - Macroalgae community structure - Feeding selectivity $\cdot$ Fish grazing

\section{INTRODUCTION}

The importance of herbivorous fishes in tropical marine waters has been extensively documented in the last 40 yr (Horn 1989, Choat 1991). In these environ-

\footnotetext{
-E-mail: pojeda@genes.bio.puc.cl

- Present address: Departamento de Ciencias Ecológicas, Facultad de Ciencias, Universidad de Chile, Casilla 653, Santiago, Chile
}

ments, this group has been shown to play a major role in shaping the abundance, distribution and diversity patterns of macroalgal assemblages (e.g. Randall 1961, John \& Pople 1973, Ogden \& Lobel 1978, Lubchenco \& Gaines 1981, Lewis 1986, Hixon \& Brostoff 1996, Ferreira et al. 1998, Miller \& Hay 1998).

In contrast, and based on ecophysiological and biogeographical considerations, it has been proposed that herbivorous fishes are rare in temperate waters, and consequently of minor ecological importance in deter- 
mining macroalgal community structure (Quast 1968, Lubchenco \& Gaines 1981, Choat 1982. Horn 1989, Ebeling \& Hixon 1991). The effects of herbivory on macroalgal abundance, distribution and diversity patterns in temperate rocky subtidal and intertidal areas have almost always been ascribed to grazing invertebrates such as gastropods and sea urchins (e.g. Paine \& Vadas 1969, Lubchenco 1978, Underwood \& Jernakoff 1984, Contreras \& Castilla 1987, Metaxas \& Scheibling 1993).

Recent studies, however, indicate that herbivorous fishes are important components of littoral fish assemblages in temperate waters (Choat \& Clements 1992 , Barry \& Ehret 1993, Cáceres et al. 1994, Horn \& Ojeda 1999), which in turn suggests that their ecological role may have been underestimated. Further, the effects of herbivorous fishes on macroalgae have been shown in the few instances and places where they have been investigated in temperate subtidal waters (Foster 1975, Harris et al. 1984, Andrew \& Jones 1990, Sala \& Boudouresque 1997, but see Jones 1992). Nevertheless, similar studies have not been undertaken in temperate intertidal areas.

The paucity of studies investigating the effects of herbivorous fishes in temperate waters is striking if one considers that many of them have been shown to be highly selective in their feeding habits (e.g. Horn et al. 1982, 1990, Barry \& Ehret 1993, Cáceres et al. 1994, Horn \& Ojeda 1999), with most preferring green and red foliose macroalgae over brown, encrusting and calcareous macroalgae. It follows that, if their numerical abundance in these habitats were also found to be high, their marked feeding selectivity could be an indication of them having a major role in determining macroalgal community structural patterns. Therefore, there is an essential need to investigate concurrently feeding habits, diet selectivity and effects of herbivorous fishes on macroalgal abundance, distribution, and diversity patterns in temperate marine habitats, and especially rocky intertidal areas.

Preference for different macroalgal species by temperate marine herbivorous fishes has been explained by a number of factors, including: temporal and spatial variation in food availability (Horn et al. 1986, Cáceres et al. 1994), food quality in terms of energy and nutrient contents (Montgomery \& Gerking 1980, Horn et al. 1982, 1986, 1990), and presence of chemical deterrent compounds and toughness (Littler \& Littler 1980, Hay et al. 1988, Hay \& Fenical 1992). Based on an analysis of ash, energy, and nutrient content, as well as digestibility, Montgomery \& Gerking (1980) concluded that green macroalgae were better food than red macroalgae, and red were better than brown macroalgae.

In this study, we concurrently determined the feeding habits and field and laboratory food selectivity of the Chilean comb-tooth blenny Scartichthys viridis and evaluated its effects on macroalgal abundance, distribution and diversity patterns in a rocky intertidal site on the temperate coast of central Chile. This species is the most abundant and only herbivorous fish species inhabiting rocky intertidal areas along the Chilean central coast (Muñoz \& Ojeda 1997), representing over $18 \%$ of the total number of fish individuals in 18 species collected in the last $8 \mathrm{yr}$ (Ojeda unpubl. data). $S$. viridis has been reported to be a grazer (Stepien 1990, Muñoz \& Ojeda 1997), consuming both green and red macroalgae. Nevertheless, nothing is known about its dietary preferences when offered a choice of different macroalgae or how its diet relates to the field availability of different algae.

Our aims were to: (1) describe the diet of Scartichthys viridis in detail; (2) determine its food selectivity in the field by comparing gut contents with field availability of macroalgae; (3) report on its laboratory dietary preferences in a multiple-choice feeding experiment; and (4) evaluate and compare the relative effects of this fish and grazing invertebrates on macroalgal abundance, distribution and diversity patterns, using replicated exclusion cages, in a rocky intertidal site in central Chile.

We hypothesized that Scartichthys viridis would select green foliose macroalgae over red and brown foliose species in the field and laboratory due to their reported greater energy and nutrient content. Secondly, due to the high abundance of this fish herbivore in the studied system, if green macroalgae were preferred over others, we hypothesized that the exclusion of herbivorous fish would result in a significant increase over time in the abundance of these macroalgae and not of non-selected algal species. Finally, we predicted a significantly greater growth of green foliose species in the fish exclusion cages in comparison to the control (no exclusion).

\section{METHODS}

Fish collections. We collected fish in rocky intertidal areas at 3 localities along the central Chilean coast: Las Cruces $\left(33^{\circ} 30^{\prime} \mathrm{S}, 71^{\circ} 38^{\prime} \mathrm{W}\right)$. El Tabo $\left(33^{\circ} 27^{\prime} \mathrm{S}\right.$, $\left.71^{\circ} 37^{\prime} \mathrm{W}\right)$, and Los Molles ( $\left.32^{\circ} 14^{\prime} \mathrm{S}, 71^{\circ} 32^{\prime} \mathrm{W}\right)$, either by hook and line fishing, or with hand nets and snorkels aided by a Benzocaine $-96^{\circ}$ alcohol solution or Rotenone (75 to $100 \mathrm{ml} \mathrm{m}^{-3}$ ) from March 1994 to April 1995. We captured fish from both tidepools and intertidal channels. We placed all captured fish in labeled plastic bags and transported them frozen to the laboratory, where they were stored at $-18^{\circ} \mathrm{C}$. In the laboratory, each. specimen was thawed, measured to the nearest mm (total length $=T L$ ), and weighed to the nearest $0.01 \mathrm{~g}$. 
Dietary analyses and field feeding preferences. Stomachs and intestines were cut open and gut contents removed. The gut contents were then subjected to a quick wash with tap water and were sorted; food items were identified to genus level. Identification to species level was not possible in some cases because the food items were partially digested. Each item was damp-dried on paper towel and wet weighed with $1 \mathrm{mg}$ accuracy. The relative importance of each item in the diet was expressed as percentage frequency of occurrence ( $\% \mathrm{FO})$, and percentage of the total biomass of food ( $\% \mathrm{~W})$. We used plots of cumulative Shannon $\left(H^{\prime}\right)$ gut content diversity (which were calculated from values of $\% \mathrm{~W}$ ), to determine adequate sample size as in Muñoz \& Ojeda (1998). Cumulative diversity values were calculated by combining groups of samples (digestive tracts) ranging from 1 to all guts examined, and plotted against the number of guts combined. We considered sample size to be adequate when gut content diversity stabilized. Adequate sample size was found to be between 25 and 30 specimens. We evaluated seasonal dietary changes using Kendall's Rank Correlation test (Siegel \& Castellan 1988). In this study, macroalgae are defined as kelp, small and turfing foliose species, and crustose forms (Hoffmann \& Santelices 1997).

We determined field diet selectivity of Scartichthys viridis twice, fall-winter 1994 and spring-summer 1994-95, at Las Cruces by comparing gut contents of individuals caught at Las Cruces with the abundance of macroalgae found in the area of the intertidal zone where fish were collected. This was done by sampling all macroalgae found within fifteen $20 \times 20 \mathrm{~cm}$ quadrats placed along a transect on one of the walls of an intertidal channel, which was perpendicular to the shore line. We stationed quadrats $1 \mathrm{~m}$ apart, and just above the water level at low tide. The channel was approximately $30 \mathrm{~m}$ long and 2 to $3 \mathrm{~m}$ wide.

In the laboratory, we analyzed the samples in the same manner as the gut contents. The relative importance of each macroalgal genus was expressed as the percentage of total available macroalgal biomass $(\% W)$. Adequate sample size was found to be between 8 and 12 quadrats.

We used the Linear Resource Selection Index ( $L$ in Strauss 1979) to assess preferences of Scartichthys viridis for the different macroalgae found in the field. This index is based on the relationship $L=r_{i}-p_{i \prime}$ where $L$ is the measure of preference, $i=$ macroalgal taxon, $r$ = relative utilization of different macroalgae (as found in the gut contents), and $p=$ overall field proportional availability of that food type, with $r$ and $p$ each expressed as \%W. Index values range from -1 to +1 , with negative values indicating non-preference (avoidance) and positive values indicating preference.
Laboratory prey choice experiments. Preference for different macroalgal species was evaluated through multiple-choice feeding experiments, which were carried out at the Coastal Marine Research Station (ECIM) of the P. Universidad Católica de Chile at Las Cruces during July-August 1995 (winter). We collected live specimens from tidepools using the anesthetic BZ 20 (Veterquímica, Chile).

To test the null hypothosis that Scartichthys riridis preys equally on different macroalgal species, we used 8 groups of fish ( 7 to $21 \mathrm{~cm} \mathrm{TL),} \mathrm{each} \mathrm{consisting} \mathrm{of} 3$ similarly sized individuals. Groups of 3 individuals were used because, in preliminary experiments, we found that isolated fish seldom fed. Each group of 3 fish was considered 1 replicate. Fish were acclimated, without food, for $1 \mathrm{wk}$ in $180 \mathrm{l}$ aquarium tanks (1 group aquarium $^{-1}$ ), with circulating sea water at 8 to $10^{\circ} \mathrm{C}$ (winter mean sea water temperature) and constant aeration, before we initiated the experiments. Protective refuges were provided by PVC tubing.

At the start of the experiments, we offered each group similar amounts (approximate biomass) of the 7 most abundant species of macroalgae present at Las Cruces the green Ulva rigida, Enteromorpha linza, and Codium dimorphum; the brown Colpomenia phaeodactyla; and the red Corallina officinalis, Gelidium chilense and Mazzaella laminarioides) (Hoffmann \& Santelices 1997, Muñoz pers, obs.). With the exception of $M$. laminarioides, all these species were found, to a greater or lesser extent, in the gut contents of Scartichthys viridis. Each macroalgal species was offered attached to its original rock piece because preliminary experiments showed that $S$. viridis did not eat artificially attached macroalgae (e.g. attached to plastic rods via rubber bands) due to the nature of its feeding mechanism, i.e. grazing. The 7 rock pieces, each with 1 macroalgal species attached, were randomly placed, forming a circle at the center of the aquarium, each piece separated from the next by approx. $5 \mathrm{~cm}$. We recorded the feeding activities of each group for $1 \mathrm{~h}$, using a Canon L1 $8 \mathrm{~mm}$ video camera placed on a tripod. We later counted the number of bites on each macroalgal species and analyzed the results for significant differences.

Preference rankings (order of choice) among groups of fish for the different macroalgal species offered were calculated and statistically compared through Kendall's coefficient of concordance $(W)$ to test for homogeneity of choice (Siegel \& Castellan 1988). We did not detect statistical differences among the 8 groups of fish with regards to the order (rankings) of their preferences $(W=0.82, p<0.01)$. Having established that the among-group selectivities did not differ, we tested the null hypothesis of equal preference for the different macroalgae using Friedman's test (Zar 
1996), which may be used when samples are not independent (Conover 1981), thus taking into account the recommendations made by Peterson \& Renaud (1989) and Roa (1992) for prey selectivity experiments, and where the normality requirement is not met.

For the null hypothesis to be rejected at the level of $\alpha=0.05$, the Friedman test statistic, $T_{2}$ has to exceed the $F$ distribution value with $k_{1}=k-1$ and $k_{2}=(b-1)$ $(k-1)$ degrees of freedom, where $k=$ number of species of macroalgae offered (7) and $b=$ number of groups of fish tested (8). A posteriori multiple comparisons were made if equal preference was rejected (Conover 1981, p. 300).

Fish and invertebrate herbivore exclusion cage experiment. We conducted an herbivore exclusion experiment in a large ( 0.5 ha) area in a rocky mid-intertidal zone at Las Cruces from December 1995 to May 1996 in which we selectively excluded fish from some rocky surfaces and invertebrates from others, in order to examine separately the impact of fish and invertebrates on macroalgal abundance, diversity and distribution. This area consisted of channels, formed by heterogenous, broken rocky outcrops and large stable boulders, which were completely covered by water during high tides and isolated from the sea at low tides. These channels are very common in rocky intertidal areas along the central Chilean coast. The rocky surfaces of vertical walls, large and small boulders, as well as platforms at this study site were largely bare of foliose macroalgae such as Ulva rigida, Gelidium chilense, Ceramium spp., Colpomenia phaeodactyla, Mazzaella laminarioides, Porphyra columbina and Enteromorpha linza. Instead, the rocky surfaces were mostly covered by crustose red and brown macroalgae (e.g. Hildenbrandia lecanellieri and Ralfsia confusa).

Table 1 Scartichthys viridis. Gut contents of 115 specimens collected in rocky intertidal areas on the central Chilean coast, 1994-95. The importance of each item is expressed as: frequency of occurrence in the digestive tracts (FO), percentage of FO $(\% \mathrm{FO})$, total biomass $(\mathrm{W})$ in $\mathrm{g}$, and percentage of total food biomass $(\% \mathrm{~W})$

\begin{tabular}{|c|c|c|c|c|}
\hline Food item & $\mathrm{FO}$ & $\% \mathrm{FO}$ & $W(g)$ & $\% W$ \\
\hline \multicolumn{5}{|l|}{ Macroalgae } \\
\hline \multicolumn{5}{|l|}{ Chlorophyta } \\
\hline Chaetomorpha & 16 & 13.9 & 0.059 & 0.1 \\
\hline Cladophora & 6 & 5.2 & 0.009 & $<0.1$ \\
\hline Codium & 10 & 8.7 & 0.269 & 0.6 \\
\hline Enteromorpha & 86 & 74.8 & 1.527 & 3.6 \\
\hline Rhizoclonium & 1 & 0.9 & 0.001 & $<0.1$ \\
\hline Ulva & 93 & 80.9 & 13.977 & 32.6 \\
\hline \multicolumn{5}{|l|}{ Phaeophyta } \\
\hline Colpomenia & 15 & 1.3 .0 & 0.404 & 0.9 \\
\hline Ectocarpus & 4 & 3.5 & 0.004 & $<0.1$ \\
\hline Giffordia & 4 & 3.5 & 0.011 & $<0.1$ \\
\hline Glossophora & 1 & 0.9 & 0.003 & $<0.1$ \\
\hline Halopteris & 18 & 15.7 & 0.067 & 0.2 \\
\hline Petalonia & 3 & 2.6 & 0.051 & 0.1 \\
\hline Pilayella & 2 & 1.7 & 0.002 & $<0.1$ \\
\hline Ralfsia & 17 & 14.8 & 0.837 & 2.0 \\
\hline \multicolumn{5}{|l|}{ Rhodophyta } \\
\hline Acrochaetium & 2 & 1.7 & 0.022 & $<0.1$ \\
\hline Ahnfeltia & 6 & 5.2 & 0.041 & $<0.1$ \\
\hline Ceramiales ${ }^{a}$ & 68 & 59.1 & 3.031 & 7.1 \\
\hline Corallina & 19 & 16.5 & 0.678 & 1.6 \\
\hline Dendrymenia & 1 & 0.9 & 0.068 & 0.2 \\
\hline Gastroclonium & 18 & 15.7 & 0.251 & 0.6 \\
\hline Gelidium & 56 & 48.7 & 17.737 & 41.4 \\
\hline Plocamium & 2 & 1.7 & 0.002 & $<0.1$ \\
\hline Rhodymenia & 3 & 2.6 & 0.181 & 0.4 \\
\hline Schottera & 9 & 7.8 & 0.153 & 0.4 \\
\hline Unidentified macroalgae & 31 & 27.0 & 0.380 & 0.9 \\
\hline Total macroalgae & 100 & 87.0 & 39.675 & 92.8 \\
\hline Invertebrates & 68 & 59.1 & 3.063 & 7.2 \\
\hline
\end{tabular}


Visual observations at the study site showed that the abundance of Scartichthys viridis was fairly high, with an estimated density of 1 individual per $4 \mathrm{~m}^{2}$. Omnivorous fishes, such as the browser Girella laevifrons, are largely absent, being found only in high intertidal rockpools. The herbivorous sea urchins Tetrapygus niger and Loxechinus albus are rare in this area, with only a few individuals occurring in nearby tidepools. Grazing limpet gastropods (e.g. Fissurella crassa and Collisella ceciliana), measuring 20 to $40 \mathrm{~mm}$ in shell length, were found at densities ranging from 5 to 10 ind. $\mathrm{m}^{2}$. Tiny littorinid Littorina araucana individuals (1 to $3 \mathrm{~mm}$ ) occurred as aggregates inside crevices. A few chitons Chiton granosus were present at a density of about 1 individual per $10 \mathrm{~m}^{2}$ and measuring 8 to $10 \mathrm{~cm}$ in length. Barnacles Jehlius cirratus and Chthamalus scabrosus occurred in small patches covering not more than $5 \%$ of the rocky surfaces.

We applied 4 experimental treatments, which were each replicated 10 times. These treatments consisted of (1) fish exclusion, (2) invertebrate exclusion, (3) 'cageroof' control, and (4) control (no exclusion). The 2 exclusion and the cage-roof control treatments used replicated cages that had $25 \times 25 \times 20 \mathrm{~cm}$ stainless steel frames totally or partially (depending on treatment, see below) covered with $8 \mathrm{~mm}$ galvanized chicken wire mesh, and treated with anti-fouling and anti-oxidant paints. We fixed each cage on approximately flat $25 x$ $25 \mathrm{~cm}$ rocky surfaces with $8 \mathrm{~cm}$ screws at each cage corner. The fish exclusion treatment cages allowed access to limpet gastropods and other small invertebrates through $2 \mathrm{~cm}$ high spaces in the mesh at the bottom of the sides, while preventing the entry of fish. Therefore, only the effect of excluding fish was evaluated through these cages. The sides of the invertebrate exclusion cages were completely covered with wire mesh, but no roof was added; thus herbivorous invertebrates were prevented from entering and fish were allowed access from above (height $20 \mathrm{~cm}$ ). Therefore, only the effect of excluding herbivorous invertebrates was evaluated through these cages. A cage-roof control treatment evaluated potential caging artefacts, such as light reduction and water retention effects. The cages used in this treatment consisted of the same stainless steel frames, with the roof but not the sides covered with galvanized chicken wire, thus allowing access to both fish and invertebrates. Ten fairly flat control rocky substrata were also randomly chosen; these were demarcated with screws at each corner. Percentage cover of foliose macroalgae initially did not exceed $5 \%$ and canopy height was 3 to $5 \mathrm{~mm}$ (volume $<15 \mathrm{~cm}^{3}$ surface ${ }^{-1}$ ); these were similar for all experimental and control substrata. As mentioned above, cover consisted mostly of brown and red crustose macroalgae.
We monitored each cage and control every $2 \mathrm{wk}$ for $150 \mathrm{~d}$. Foliose macroalgal cover and canopy height were measured by using the point-intercept method (100 points) and a vertical ruler randomly placed at 10 points inside the quadrat, respectively. Percentage cover was transformed into area $\left(\mathrm{cm}^{2}\right)$ and multiplied by mean canopy height, resulting in an estimate of macroalgal volume $\left(\mathrm{cm}^{3}\right)$. We used macroalgal volume in the analyses because it is more representative of the abundance of foliose macroalgae than percentage cover alone. We analyzed temporal changes in macroalgal abundance among treatments using a 1-way repeated measures ANOVA, after testing for normality using the Shapiro-Wilks test (Zar 1996). Foliose macroalgal diversity also was recorded during each monitoring event, estimated as the number of species present.

\section{RESULTS}

\section{Diet}

A total of 115 Scartichthys viridis specimens, ranging in size from 40 to $302 \mathrm{~mm}$ TL, with a mean $\pm 1 \mathrm{SD}=147$ $\pm 69 \mathrm{~mm}$, were analyzed. Mean biomass of these fish was $75.67 \pm 97.44$ (1 SD) g, ranging from 0.50 to $394.05 \mathrm{~g}$

Macroalgae represented almost $93 \%$ of the total food biomass found in the gut contents of Scartichthys viridis (Table 1). Only 8 of the 115 fish had empty guts, and $100(87 \%)$ contained macroalgae. Thirty macroalgal genera were identified, including 6 Chlorophyta, 8 Phaeophyta and 16 Rhodophyta. Two genera formed the bulk of the total gut contents. In terms of percentage biomass, these were the turf-forming red macroalga Gelidium $(41.4 \%)$ and the green sea lettuce Ulva $(32.6 \%)$. In terms of percentage frequency of occurrence, the most common items were Ulva found in $80.9 \%$ of guts examined), the green Enteromorpha $(74.8 \%)$, various red macroalgae belonging to the order Ceramiales (which lumped together were found in $59.1 \%$ of guts), and Gelidium (48.7\%). Brown macroalgae, in comparison to the red and green macroalgae, were unimportant in terms of percentage biomass and frequency of occurrence (Table 1).

Animal gut contents represented only $7.2 \%$ of the total biomass and consisted of tiny amphipods, gastropods and bivalves, which live associated with the macroalgal turf. Almost all guts analyzed contained inorganic sediment, representing about 2 to $5 \%$ of the volume of the gut contents. Diatoms and detritus also contributed, to a small degree, towards this fish's diet, together forming approximately 5 to $10 \%$ of the volume of the gut contents. Nevertheless, the importance 
of these items is difficult to quantify gravimetrically as they were always mixed with partially digested macroalgal food items. No seasonal dietary differences were found at Las Cruces (Kendall's Rank Correlation test, $T=$ $0.75, p<0.05)$ or at Los Molles $(T=0.8$, $p<0.05)$. At El Tabo, fish were collected during spring-summer only.

\section{Field feeding preferences}

The different species of macroalgae making up most of the biomass at the study site were not consumed in proportion to their relative percentage availability in the field in either of the 2 seasons (Table 2). Ulva was selected during both fall-winter and spring-summer ( $L=0.10$ and 0.16 , respectively). Gelidium also was consumed preferentially during fall-winter $(L=0.20)$, and during spring-summer it was taken in proportion to its field availability (Table 2). On the other hand, Codium, Gastroclonium, and Corallina were rejected, whereas the rest of the genera were consumed in similar proportion to their field availability (e.g, order Ceramiales). The only species of Ulva and Codium present in our study site were $U$. rigida and $C$. dimorphum; more than $80 \%$ of Gelidium corresponded to $G$. chilense, the rest being $G$. lingulatum.

Table 2. Scartichthys viridis. Field food selectivity in a rocky intertidal area at Las Cruces, central Chile, estimated using the Linear Resource Selection Index ( $L$ in Strauss 1979), based on percentage field availability and percent contribution to its diet, of the 7 most abundant macroalgal genera in its gut contents during fall-winter 1994 and spring-summer 1994-95. Values range from +1 to -1 , indicating maximal to minimal preference, respectively. $\mathrm{C}=$ Chlorophyta, $\mathrm{P}=$ Phaeophyta, $R=$ Rhodophyta

\begin{tabular}{|lccc|}
\hline Macroalgae & $\begin{array}{c}\text { Contribution to diet } \\
\text { (\% wet biomass) }\end{array}$ & $\begin{array}{c}\text { Field availability } \\
\text { (\% wet biomas) }\end{array}$ & $\begin{array}{c}\text { Selectivity } \\
(\mathrm{L})\end{array}$ \\
\hline Fall-winter 1994 & & & \\
Gelidium (R) & 51.6 & 31.2 & 0.20 \\
Ulva (C) & 31.9 & 21.7 & 0.10 \\
Ceramiales (order, R) & 6.6 & 12.5 & -0.06 \\
Ralfsia (P) & 2.6 & 0.1 & 0.03 \\
Corallina (R) & 1.9 & 11.5 & -0.10 \\
Colpomenia (P) & 1.2 & 0.1 & 0.01 \\
Codium (C) & 0.8 & 22.4 & -0.22 \\
Spring-summer 1994-95 & & & \\
Gelidium (R) & 46.8 & 43.5 & 0.03 \\
Ulva (C) & 36.8 & 20.0 & 0.16 \\
Ceramiales (order, R) & 7.7 & 4.8 & 0.03 \\
Enteromorpha (C) & 2.4 & 0.1 & 0.02 \\
Corallina (R) & 2.3 & 15.9 & -0.14 \\
Gastroclonium (R) & 0.8 & 11.1 & -0.10 \\
Halopteris (P) & 0.6 & 0.4 & $<0.01$ \\
\hline - & & & \\
\hline
\end{tabular}

\section{Laboratory prey choice experiments}

Scartichthys viridis individuals strongly preferred (or avoided) certain macroalgal species in the multiplechoice feeding experiments, rejecting the null hypothesis of equal preference (Friedman test, $T_{2}=29.79, \mathrm{p}<$ 0.05; Table 3). All groups tested preferred green over red or brown macroalgae. Mean feeding rate (number of bites per hour) on the green macroalga Ulva rigida $(167 \pm 28,1 \mathrm{SE})$ was significantly greater than that on the other 6 species offered (Table 3). The green macroalgae Codium dimorphum and Enteromorpha linza were the next most preferred items, while all other species offered (both red and brown macroalgae) were noticeably avoided. Interestingly, the red macroalga Gelidium chilense was one of the least preferred species ( $6 \pm 2$ bites $\mathrm{h}^{-1}$, Table 3 ).

\section{Fish and invertebrate herbivore exclusion cage experiment}

The cages were effective in excluding either fish or invertebrates. Field observations during high tide from plat. forms next to the channels and at dif. ferent times during the running of the experiment showed that Scartichthys viridis swimming in the vicinity did not enter the fish exclusion cages. On only 2 occasions were individual limpets found in the invertebrate exclusion cages (1 limpet in 2 different replicate cages, at Days 90 and 105); they were removed when found. As expected, limpets were found inside the fish exclusion cages, and $S$. viridis inside the invertebrate exclusion cages 
Fish exclusion produced significant changes in foliose macroalgal abundance, which rapidly increased on the surfaces, reaching a maximum (mean = $7300 \mathrm{~cm}^{3}$; Fig. 1a) at $75 \mathrm{~d}$. Significant differences in the amount (volume) of foliose macroalgae among treatment and through time were detected (1-way repeated measures ANOVA: effect of treatment, $F_{3,37}=12.883$, $\mathrm{p}<0.01_{\text {; }}$ effect of time, $F_{10.370}=4.235, \mathrm{p}<0.01$ ). Macroalgal volume within fish exclusions differed significantly from that which developed under the other 3 treatments (invertebrate exclusion, cage-roof control and control), (a posteriori Tukey test: $p<0.01$ ), which, in turn, did not differ from each other $(p>0.05)$. The fact that total macroalgal growth did not differ between the control and the cage-roof control suggests that caging artifacts were unlikely to have been present.

The volume of green foliose Ulva rigida and Enteromorpha linza rapidly increased in the fish exclusion cages, reaching a maximum (mean $=2500 \mathrm{~cm}^{3} ;$ Fig. 1 b) at $60 \mathrm{~d}$. The percentage cover of these macroalgae approached $100 \%$, and canopy height was over $8 \mathrm{~cm}$ on some surfaces. In contrast, no consistent increase was detected where invertebrates were excluded or under the cage-roof treatment or control (no herbivores excluded) (Fig. 1b). Significant differences in the amount (volume) of green macroalgae present under the different treatments and through time were detected (1-way repeated measures ANOVA: effect of treatment, $F_{3,37}=20.578, p<0.01$; effect of time, $F_{10,370}$ $=5.392, \mathrm{p}<0.01$ ). The volume of green macroalgae that developed where fish were excluded differed significantly from that which appeared under the 3 other treatments (a posteriori Tukey test: $\mathrm{p}<0.01$ ), which in turn did not differ from each other $(p>0.05)$.

Although the volume of red and brown foliose macroalgae also increased on some of the fish exclusion surfaces, there was a delay in their growth in comparison to green macroalgae (Fig. 1c). These consisted of the red macroalgae Gelidium chilense, Porphyra columbina, and Mazzaella laminarioides and the brown macroalgae Colpomenia phaeodactyla and Petalonia fascia. The abundance of these species started to increase in the fish exclusion surfaces after 15 to $30 \mathrm{~d}$, representing a tiny fraction $(<1 \%)$ of the total foliose macroalgal volume present, and peaked after $75 \mathrm{~d}$ with a mean of $700 \mathrm{~cm}^{3}$ (Fig. 1c). A number of $P$. columbina fronds reached $>14 \mathrm{~cm}$ in height. The brown $C$. phaeodactyla occurred only on the fish exclusion surfaces, and only Ulva rigida grew within invertebrate exclusions. No significant differences were detected in the volume of brown and red foliose macroalgae among the fish exclusion, cage-roof control and control treatments (1-way repeated measures ANOVA: effect of treatment, $F_{2,27}=1.073, \mathrm{p}=0.35$; a) all foliose macroalgae

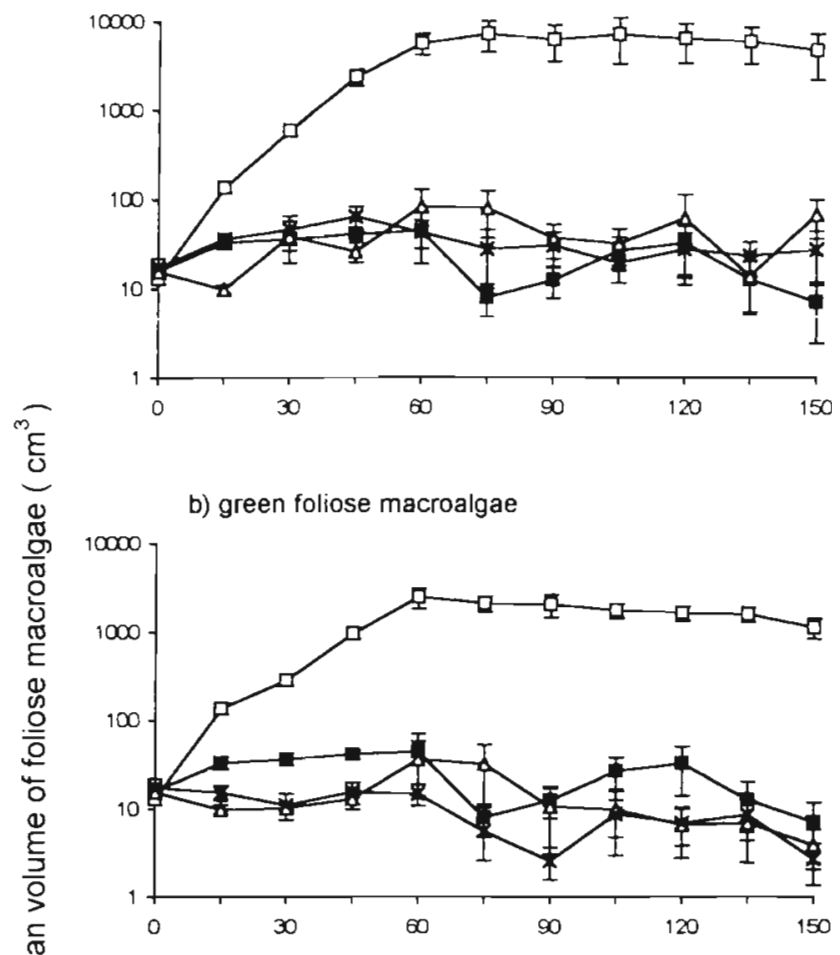

c) brown and red foliose macroalgae

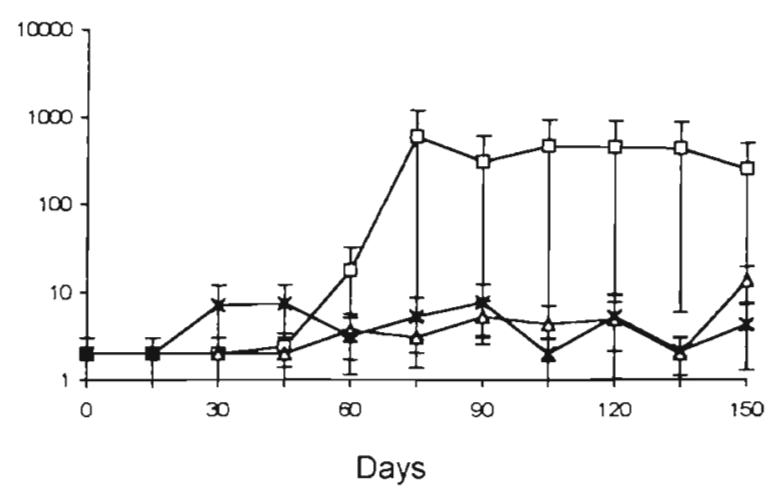

$\begin{array}{ll}\rightarrow-\text { Fish exclusion } & \rightarrow-\text { Invertebrate exclusion } \\ -\Delta-\text { Cage - roof control } & x \text { - Control }\end{array}$

Fig. 1. Abundance (volume) of foliose macroalgae (mean \pm 1 $\mathrm{SE}$ ) through time on rocky surfaces in a mid intertidal area in central Chile, under 4 different experimental treatments: fish exclusion, invertebrate exclusion, cage-roof control, and control (no exclusion). Each treatment has 10 replicates. (a) All foliose macroalgae, (b) green foliose macroalgae, (c) brown and red foliose macroalgae. Note logarithmic ordinate

effect of time, $F_{10.270}=1.135, p=0.33$ ). The invertebrate exclusion treatment was excluded from this analysis because no brown and red algae developed on these surfaces. The absence of significant differ- 
ences is due to high within-treatment variability in the amount of brown and red foliose macroalgae on the fish exclusion substrata, indicated by the large standard error values (Fig. 1c). Small amounts of sediment were observed in a few cages, usually not covering more than 3 to $5 \%$ of the surfaces.

Mean number of foliose macroalgal species per treatment did not vary throughout the experiment, averaging 2 species per treatment. Total number of species per treatment varied through time $(2$ to 6 species), apparently stochastically, except for the invertebrate exclusion cages, where only Ulva rigida was found.

Cages were removed after $150 \mathrm{~d}$ and most macroalgal biomass disappeared, with only a few small patches remaining in some areas. Scartichthys viridis scrape marks were clearly visible on many of the rock surfaces

\section{DISCUSSION}

In this study, we have demonstrated that Scartichthys viridis has an herbivorous diet, primarily consuming the foliose macroalga Gelidium (Rhodophyta) and Ulva (Chlorophyta). Diets of other rocky intertidal herbivorous fishes are also dominated by green and red macroalgae (e.g. Bennett et al. 1983, Barry \& Ehret 1993, Horn \& Ojeda 1999). Selectivity for these macroalgae has been explained in terms of their greater protein, caloric and digestibility values in comparison to brown macroalgae (Montgomery \& Gerking 1980, Benavides et al. 1986, Cáceres et al. 1994, Horn \& Ojeda 1999, Cáceres \& Ojeda in press).

\section{Field and laboratory diet selectivity}

In the multiple-choice feeding experiments, Scartichthys viridis selected the green macroalgae Ulva rigida, Enteromorpha linza and Codium dimorphum, while the red macroalga Gelidium chilense was rejected. Horn et al. (1982) found that 2 stichaeid fishes, Cebidichthys violaceus and Xiphister mucosus, occurring in rocky intertidal habitats in California, also selected Ulva in multiple-choice experiments, while Barry \& Ehret (1993) showed similar results for the kyphosid Girella nigricans. Green macroalgae have traditionally been considered better food items than red macroalgae, based on energetic and nutrient content, as well as greater digestibility (Paine \& Vadas 1969, Montgomery \& Gerking 1980, Horn 1989). Nevertheless, this statement has been questioned. For example, Paine \& Vadas (1969) reported very similar energetic contents for Enteromorphasp., U. rigida, and Gelidium cartilagineum from the Washington coast.
Recently, Cáceres \& Ojeda (in press) found percentage protein, carbohydrates, and ash to be similar among $U$. rigida, E. linza and $G$. chilense in central Chile, while assimilation efficiency for these macroalgae by $S$. viridis did not differ significantly. Further, energetic content did not differ substantially between $U$. rigida and $G$. chilense (Ojeda unpubl. data).

Then, why did this species reject Gelidium chilense in laboratory multiple-choice experiments, considering that this red macroalga forms an important part of its diet? We hypothesize that although Ulva rigida, Enteromorpha linza and $G$. chilense are equivalent, Scartichthys viridis actively selects the green macroalgae because they are more easily dislodged from rock substrata and are not as tough. The mechanical force necessary for dislodging Gelidium is probably greater than for Ulva or Enteromorpha. Further, Gelidium is attached by creeping axes with many stolons, and is quite tough, consisting of profusely branched thalli containing several layers of cells, including cortex and medulla (Hoffmann \& Santelices 1997). In contrast, Ulva and Enteromorpha consist of soft and very thin sheet-like, 2-cell layered thalli (Hoffmann \& Santelices 1997).

Why does Scartichthys viridis consume Gelidium in the field? Although UIva is preferred, there may not be enough available biomass to sustain the large population sizes of this blenny along the central Chilean coast (Cáceres \& Ojeda in press). Therefore, the inclusion of a lower quality (due to its toughness and structure) but more abundant food item such as Gelidium may be necessary under these circumstances. This leads to the prediction that Gelidium should be selected only when the amount of UIva available is low. Some evidence supports this hypothesis, since Gelidium was selected in the field only during fall-winter (Table $2 ; L=0.20$ ), when the field biomass of Ulva was only $19.0 \mathrm{~g} \mathrm{~m}^{-2}$. In contrast, Gelidium was taken only in proportion to its field availability in spring-summer ( $L=0.03)$, when the amount of UIva in the field had more than doubled $\left(42.2 \mathrm{~g} \mathrm{~m}^{-2}\right)$.

The selection of Codium dimorphum in our laboratory experiments is puzzling and contrasts with their field selectivity and gut contents. Codium is perhaps consumed by Scartichthys viridis in the field, but disintegrates, as its thalli consist of profusely branched tubular coenocytic cells (Hoffmann \& Santelices 1997). Also, the digestion rate may be faster due to its structure.

\section{Feeding mechanism and food selectivity in temperate waters}

Herbivorous fishes are classified as either grazers or browsers (Horn 1989). Jones (1968) suggested that 
grazers pick up inorganic sediment while feeding by scraping or sucking, whereas browsers bite or tear more upright macroalgae and rarely ingest any inorganic material. The type of macroalgae that Scartichthys viridis consumes, together with the finding of inorganic sediment in its gut contents and feeding observations, demonstrates that this species is a grazer.

The prevailing notion is that grazers feed non-selertively because their macroalgal food is small and tightly adhered to the substratum (Choat 1982, but see Horn et al, 1990), whereas most browsers select larger macroalgae (Choat \& Clements 1992, Cáceres et al. 1994). Further, grazing fishes are considered to be largely absent from temperate waters, which are dominated instead by browsers (Choat 1991). It has been suggested that grazing fishes, which have high metabolic rates, may be unable to sustain themselves, given the low productivity and turnover of turfing macroalgae (Choat 1991). For this reason, only invertebrate grazers (with lower metabolic rates) should be present in temperate waters. Contrary to the above 2 generalizations, we have shown in the present study that Scartichthys viridis is a grazer in a temperate system and displays a high degree of feeding selectivity.

\section{Effect of fish herbivory on macroalgal abundance, diversity and distribution}

The exclusion of herbivorous fish resulted in an enormous increase of foliose algae, particularly green macroalgae and, to a much lesser extent, red and brown macroalgae. In contrast, the exclusion of invertebrates did not produce results significantly different from those in control substrata, both remaining almost bare of foliose species. To our knowledge, this is the first experimental study demonstrating significant effects of an herbivorous fish on macroalgal abundance in a temperate rocky intertidal area, although a few studies have been carried out in temperate subtidal reefs (Foster 1975, Harris et al. 1984, Andrew \& Jones 1990, Sala \& Boudouresque 1997).

Although Scartichthys viridis is the only fish species that is strictly herbivorous in rocky intertidal areas along the coast of central Chile (Muñoz \& Ojeda 1997), it may be argued that other fishes also consume macroalgae and could have contributed to the effects observed. Candidate species are the clingfish Sicyases sanguineus, the kyphosid Girella laevifrons, and the blenny Hypsoblennius sordidus, all of them omnivores, which consume invertebrate prey as well as macroalgae (Muñoz \& Ojeda 1997). Cancino \& Castilla (1988) found that only small individuals of $S$. sanguineus consumed significant amounts of macroalgae, and larger individuals ate mostly barnacles, snails and limpets. Although only the former could have a direct effect on macroalgal abundance, they are uncommon in these environments (Stepien 1990, Muñoz \& Ojeda 1997). On the other hand, although juveniles of $G$. laevifrons are highly abundant in rocky intertidal areas of central Chile, they are usually restricted to high intertidal tidepools (Varas \& Ojeda 1990), not occurring in low and mid intertidal areas, where the present study was conducted. Finally, the blenny H. sordidus is rare (Stepien 1990, Muñoz \& Ojeda 1997). Therefore, the fish exclusion effects seen in this study are likely mostly due to $S$. viridis.

Further evidence supporting the role of Scartichthys viridis comes from the observation of their comb-like teeth scrape marks, which were observed on numerous rocky surfaces in the area where the experiment was conducted. These marks are very common on intertidal rocks and boulders along the central Chilean coast. They can also easily be observed in aquaria. Paine \& Palmer (1978) mistakenly identified these scrape marks as belonging to limpets and to the clingfish Sicyases sanguineus (see Fig. 2 in Paine \& Palmer 1978), but this species does not possess the comb-like teeth typical of blennies (see Fig. 3 in Horn \& Ojeda 1999)

We hypothesized that if green macroalgae were preferred over others in the laboratory, the exclusion of herbivorous fish would result in a significant increase over time in the abundance of these macroalgae and not of non-selected algal species. This was largely upheld because large amounts of green foliose macroalgae (Ulva rigida and Enteromorpha linza) that were selected in the laboratory experiments grew in the fish exclusion cages. Non-selected macroalgae (e.g. Gelidium chilense, Mazzaella laminarioides and Colpomenia phaeodactyla) were fewer and took much longer to appear. Feeding selectivity by Scartichthys viridis thus may be determining which macroalgal species are most abundant on these rocky mid intertidal areas. Fish exclusion resulted in a system largely dominated by green foliose macroalgae, while their presence (control) resulted in a very high cover of crustose brown and red macroalgae. Further, the paucity of sessile invertebrates (e.g. barnacles and mussels) in these channels, characteristic of the central Chilean coast, may well be due to the excavating effect exerted by the grazing action of $S$. viridis, in a similar way to that shown by limpets (Steneck \& Watling 1982).

The non-dietary species Porphyra columbina grew substantially on surfaces from where fish were excluded. This species was not offered in the multiplechoice feeding tests because it grows only in high intertidal areas (Hoffmann \& Santelices 1997), which Scartichthys viridis does not reach (Varas \& Ojeda 
1990). The occurrence of $P$. columbina inside the cages extended its distribution into the mid intertidal zone. Nevertheless, as mentioned, $P$. columbina does not form part of the diet of $S$. viridis. Then, why did it appear in substrata from where fish were excluded? This question remains to be answered.

Decrease in algal diversity within invertebrate exclusions may be due to selective grazing by small limpets, such as Collisella spp. Perhaps diversity is enhanced in the rocky intertidal areas by these invertebrates laying fecal pellets containing macroalgal propagules that have passed through their guts (Santelices et al. 1983). Macroalgal propagules surviving in fecal pellets have been shown to resist longer desiccation periods and grow faster than non-ingested propagules (Santelices 1992).

Scartichthys viridis is a species widely distributed along the central coast of Chile, reaching high densities in rocky intertidal areas (Muñoz \& Ojeda 1997). The intertidal habitats, where this species occurs, are also characteristically depleted of foliose macroalgae and dominated by crustose macroalgae, and scrape marks are a common feature. These patterns together with the results presented in this study suggest that $S$. viridis plays an important role in determining abundance and distribution patterns of foliose macroalgae on a broad spatial scale along the Chilean coast.

Acknowledgements. We thank P. Chacón and M. Méndez, who participated in the fish collecting. I. Meneses and J. Correa identified some of the macroalgal taxa found in the gut contents. I. Albornoz helped with the laboratory dietary preference experiments and S. González and P. Chacón helped during the herbivore exclusion cage experiment. M. Canals provided useful statistical advice. F. Jaksic, S. Navarrete and 4 anonymous reviewers made valuable comments that improved the overall quality of the manuscript. This study was funded by FONDECYT projects 1941205, 1960254 and FONDA. O and MB (No. 3) to F.P.O. A.A.M. is currently supported by a CONICYT Doctoral Fellowship. This paper is dedicated to the memory of Dr Eduardo de la $\mathrm{Hoz}$

\section{LITERATURE CITED}

Andrew NL, Jones GP (1990) Patch formation hy herbivorous fish in a temperate Australian kelp forest. Oecologia 85 $57-68$

Barry JP, Ehret MJ (1993) Diet, food preterence, and algal availability for fishes and crabs on intertidal reef communities in southern California. Environ. Biol Fishes 37:75-95

Benavides AG, Bozinovic F, Cancino JM, Yates L (1986) Asimilación de algas por dos peces del litoral chileno: Sicyases sanguineus (Gobiesocidae) y Aplodactylus punctatus (Aplodactilidae). Medio Ambiente 8:21-26

Bennett BA, Griffiths CL, Penrith ML (1983) The diets of littoral fish from the Cape Peninsula. S Afr J Zool 12:97-104

Cáceres CW, Ojeda FP (in press) Patrones de forrajeo en dos especies de peces intermareales herbivoros de las costas de Chile: efecto de la abundancia y composición química del alimento. Rev Chil Hist Nat
Cáceres CW, Fuentes LS, Ojeda FP (1994) Optimal feeding strategy of the temperate herbivorous fish Aplodactylus punctafus: the effects of food availability on digestive and reproductive patterns. Oecologia 99:118-123

Cancino JM, Castilla JC (1988) Emersion behaviour and foraging ecology of the common Chilean clingfish Sicyases sanguineus (Pisces: Gobiesocidae). J Nat Hist 22:249-261

Choat JH (1982) Fish feeding and the structure of benthic communities in temperate waters. Annu Rev Ecol Syst 13: $423-449$

Choat JH (1991) The biology of herbivorous fishes on coral reefs. In: Sale PF (ed) The ecology of fishes on coral reefs. Academic Press, San Diego, p 120-155

Choat JH, Clements KD (1992) Diet in odacid and aplodactylid fishes from Australia and New Zealand. Aust J Mar Freshw Res 43:1452-1459

Conover WJ (1981) Practical nonparametric statistics. John Wiley and Sons, New York

Contreras S, Castilla JC (1987) Feeding behavior and morphological adaptations in two sympatric sea urchin species in central Chile. Mar Ecol Prog Ser 38:217-224

Ebeling AW, Hixon MA (1991) Tropical and temperate reef fishes: comparison of community structures. In: Sale PF (ed) The ecology of fishes on coral reefs. Academic Press, San Diego, p 509-563

Ferreira CEL, Conçalves JEA, Coutinho R, Peret AC (1998) Herbivory by the dusky damselfish Stegastes fuscus (Cuvier, 1830) in a tropical rocky shore: effects on the benthic community. J Exp Mar Biol Ecol 229:241-264

Foster MS (1975) Regulation of algal community development in a Macrocystis pyrifera forest. Mar Biol 32:331-342

Harris LG, Ebeling AW, Laur DR, Rowley RJ (1984) Community recovery after storm damage: a case of facilitation in primary succession. Science 224:1334-1338

Hay ME, Fenical W (1992) Chemical mediation of seaweedherbivore interactions. In: John DM, Hawkins SJ, Price JH (eds) Plant-animal interactions in the marine benthos Systematics Association Special Volume 46. Clarendon Press, Oxford, p 319-337

Hay ME, Renaud PE, Fenical W (1988) Large mobile versus small sedentary herbivores and their resistance to seaweed chemical defenses. Oecologia 75:246-252

Hixon MA, Brostoff WN (1996) Succession and herbivory effects of differential fish grazing on Hawaiian coral reef algae. Ecol Monogr 66:67-90

Hof mann A, Santelices B (1997) Marine flora of central Chile Ediciones Universidad Católica de Chile, Santiago

Horn MH (1989) Biology of marine herbivorous fishes Oceanogr Mar Biol Annu Rev 27:167-272

Horn MH, Ojeda FP (1999) Herbivory. In: Horn MH, Martin KLM, Chotkowski MA (eds) Intertidal fishes, life in two worlds. Academic Press, San Diego, p 197-222

Horn MH, Murray SN, Edwards TW (1982) Dietary selectivity in the field and food preferences in the laboratory for two herbivorous fishes (Cebidichthys violaceus and Xiphister mucosus) from a temperate intertidal zone. Mar Biol 67: 237246

Horn MH, Neighbors MA, Murray SN (1986) Herbivore response to a seasonally fluctuating food supply: growth potential of two temperate intertidal fishes based on the protein and energy assimilated from their macroalgal diets. J Exp Mar Biol Ecol 103:217-234

Horn MH, Murray SN, Fris MB, Irelan CD (1990) Diurnal feeding periodicity of an herbivorous blenniid fish, $P$ arablennius sanguinolentus, in the western Mediterranean In: Barnes M, Gibson RN (eds) Trophic relationships in the marine environment. Proceedings of 24th European 
Marine Biology Symposium, Oban, 4-10 October, 1989. Aberdeen University Press, Aberdeen, p 170-182

John DM, Pople W (1973) The fish grazing of rocky shore algae in the Gulf of Guinea. J Exp Mar Biol Ecol 11:81-90

Jones GP (1992) Interactions between herbivorous fishes and macro-algae on a temperate rocky reef. J Exp Mar Biol Ecol 159:217-235

Jones RS (1968) Ecological relationships in Hawaian and Johnston Island Acanthuridae (surgeonfishes). Micronesica 4:309-361

Lewis SM (1986) The role of herbivorous fishes in the orqanization of a Caribbean reef community. Ecol Monogr 56: $183-200$

Littler MM, Littler DS (1980) The evolution of thallus form and survival strategies in benthic marine macroalgae: field and laboratory tests of a functional form model. Am Nat $116: 25-44$

Lubchenco J (1978) Plant species diversity in a marine intertidal community: importance of herbivore food preference and algal competitive abilities. Am Nat 112:23-39

Lubchenco J, Gaines SD (1981) A unified approach to marine plant-herbivore interactions. I. Populations and communities. Annu Rev Ecol Syst 12:405-437

Metaxas A, Scheibling RE (1993) Community structure and organization of tidepools. Mar Ecol Prog Ser 98:187-198

Miller MW, Hay ME (1998) Effects of fish predation and seaweed competition on the survival and growth of corals. Oecologia 113:231-238

Montgomery WL, Gerking SD (1980) Marine macroalgae as foods for fishes: an evaluation of potential food quality. Environ Biol Fishes 5:143-153

Muñoz AA, Ojeda FP (1997) Feeding guild structure of a rocky intertidal fish assemblage in central Chile. Environ Biol Fishes 49:471-479

Muñoz AA, Ojeda FP (1998) Guild structure of carnivorous intertidal fishes of the Chilean coast: implications of ontogenetic dietary shifts. Oecologia 114:563-573

Ogden JC, Lobel PS (1978) The role of herbivorous fishes and urchins in coral reef communities. Environ Biol Fishes 3: $49-63$

Paine RT, Palmer AR (1978) Sicyases sanguineus: a unique trophic generalist from the Chilean intertidal zone. Copeia 1978:75-81

Editorial responsibility: Otto Kinne (Editor),

Oldendorf/Luhe, Germany
Paine RT, Vadas RL (1969) Caloric values of benthic marine algae and their postulated relation to invertebrate food preference. Mar Biol 4:79-86

Peterson $\mathrm{CH}$, Renaud PE (1989) Analysis of feeding preference experiments. Oecologia 80:82-86

Quast JC (1968) Fish fauna of the rocky inshore zone. Fish Bull US 139:35-36

Randall JE (1961) Overgrazing of algae by herbivorous marine fishes. Ecology 42:812

Roa R (1992) Design and analysis of multiple-choice feedingpreference exneriments necologia 89:509-515

Sala E, Boudouresque CF (1997) The role of fishes in the organization of a Mediterranean sublittoral community. I Algal communities. J Exp Mar Biol Ecol 212:25-44

Santelices B (1992) Digestion survival in seaweeds: an overview. In: John DM, Hawkins SJ, Price JH (eds) Plant animal interactions in the marine benthos. Systematics Association Special Volume 46, Clarendon Press, Oxford, p 363-384

Santelices B, Correa J, Avila M (1983) Benthic algal spores surviving digestion by sea urchins. J Exp Mar Biol Ecol 70 : 263-369

Siegel S, Castellan NJ (1988) Nonparametric statistics for the behavioral sciences. McGraw Hill, New York

Steneck RS, Watling L (1982) Feeding capabilities and limitations of herbivorous molluscs: a functional group approach. Mar Biol 68:299-319

Stepien CA (1990) Population structure, diets and biogeographic relationships of a rocky intertidal fish assemblage in central Chile: high levels of herbivory in a temperate system. Bull Mar Sci 47:598-612

Strauss RE (1979) Reliability estimates for Ivlev's electivity index, the forage ratio, and a proposed linear index of food selection. Trans Am Fish Soc 108:344-352

Underwood AJ, Jernakoff $P$ (1984) The effects of tidal height, wave exposure, seasonality and rock-pools on grazing and the distribution of intertidal macroalgae in New South Wales. J Exp Mar Biol Ecol 75:71-96

Varas E, Ojeda FP (1990) Intertidal fish assemblages of the central Chilean coast: diversity, abundance and trophic patterns. Rev Biol Mar Valparaíso 25:59-70

Zar JH (1996) Biostatistical analysis. 3rd edn. Prentice Hall Upper Saddle River, NJ

Submitted: November 3, 1998; Accepted: March 29, 1999

Proofs received from author(s): July 23, 1999 